\title{
HUBUNGAN ANTARA SELF-EFFICACY AKADEMIK DAN KONSEP DIRI AKADEMIK DENGAN PRESTASI AKADEMIK
}

\author{
Lisa Ratriana Chairiyati \\ Psychology Department, Faculty of Humanities, BINUS University \\ Jln. Kemanggisan Ilir III No. 45, Kemanggisan - Palmerah, Jakarta Barat 11480 \\ lisar@binus.edu
}

\begin{abstract}
This study discusses the relationship between academic self-efficacy and academic self-concept with academic achievement. The design of the study was descriptive - correlational, with a study sample of 192 children. Statistical Analysis with SPSS computer method (Statistical Package for Social Science) version 17.0 for windows is used to find out characteristics of the respondents, and the regression analysis between the two independent variables (self-efficacy and academic self-concept academic) and the dependent variable (academic achievement) produce models regression $y=2,399+0,010 x_{1}-0,008 x_{2}$. The results showed only variable Self-Efficacy (SE) contributes positively to academic achievement. It is supported by the value of t-statistic greater than 1, 645 for the value $p<0,05$. Hence it can be said that the dependent variable (academic achievement) can be predicted with self-efficacy academic.
\end{abstract}

Keywords: academic self-efficacy, academic self-concept, academic achievement

\begin{abstract}
ABSTRAK
Penelitian ini membahas tentang hubungan antara self-efficacy akademik dan konsep diri akademik dengan prestasi akademik. Rancangan penelitiannya adalah deskriptif - korelasional, dengan sample penelitian 361 anak. Analisis statistik dengan metoda komputer program SPSS (Statistical Package for Social Science) versi 17.0 for windows untuk mengetahui karakteristik responden, dan analisis regresi antara 2 variabel bebas (self-efficacy akademik dan konsep diri akademik) dan varibel terikat (prestasi akademik) menghasilkan model regresi $y=2,399+0,010 x_{1}-0,008 x_{2}$. Hasil penelitian menunjukkan hanya variabel Self-Efficacy (SE) berperan secara positif terhadap prestasi akademik. Hal ini ditunjang oleh nilai t-statistik lebih besar dari 1, 645 untuk nilai $p<0,05$, sehingga dapat dikatakan bahwa variabel terikat (prestasi akademik) dapat diprediksi dengan self-efficacy akademik.
\end{abstract}

Kata kunci : self-efficacy akademik, konsep diri akademik, prestasi akademik. 


\section{PENDAHULUAN}

Pendidikan adalah proses pengubahan sikap dan tata laku seseorang atau kelompok orang dalam usaha mendewasakan manusia, melalui upaya pengajaran dan pelatihan, serta proses, cara, perbuatan mendidik (Kamus Bahasa Indonesia Online). Perguruan tinggi sebagai suatu lembaga formal merupakan sarana untuk mencapai tujuan pendidikan tersebut. Melalui perguruan tinggi para mahasiswa belajar berbagai macam hal, untuk mencapai keterampilan, kecakapan, dan pengetahuan baru. Keberhasilan mahasiswa dalam menyesuaikan diri terhadap bidang akademiknya, dapat dilihat dari prestasi akademik yang dicapai. Menurut Setiawan (2000), prestasi akademik adalah hal yang menunjukkan suatu pencapaian tingkat keberhasilan suatu tujuan, karena usaha belajar yang telah dilakukan oleh seseorang secara optimal. Prestasi akademik terfokus pada nilai atau angka yang dicapai mahasiswa dalam proses pembelajaran di sekolah atau perguruan tinggi. Nilai tersebut terutama dilihat dari sisi kognitif untuk melihat penguasaan pengetahuan sebagai ukuran pencapaian hasil belajar.

Prestasi akademik dapat diukur melalui Indeks Prestasi (IP) maupun Indeks Prestasi Kumulatif (IPK) serta ketepatan waktu dalam menyelesaikan pendidikan. Dengan demikian, dapat dikatakan bahwa prestasi akademik merupakan indikator dari penguasaan bahan kuliah yang telah dicapai mahasiswa, dan nilai (IP/IPK) dapat dijadikan tolok ukur hasil pembelajaran terakhir dari penguasaan berbagai mata kuliah tersebut di perguruan tinggi. Indeks Prestasi Kumulatif (IPK) merupakan tolok ukur keberhasilan prestasi akademik seorang mahasiswa yang dikelompokkan berdasarkan kemampuan individu mahasiswa dengan melihat hasil studi seorang mahasiswa pada semester yang telah berjalan. Pengelompokan IPK tersebut adalah sebagai berikut: sangat baik ( IPK $\geq 3$ ), baik ( IPK $2,50-2,99$ ) cukup (IPK 2,00-2,49), kurang (IPK <2,00) (Universitas Swasta Jakarta, 2007).

Menurut Bandura (1997), self-efficacy adalah keyakinan seseorang terhadap kemampuannya. Self-efficacy dipengaruhi oleh beberapa faktor seperti pengalaman individu akan sebuah rintangan (mastery experience), serta pengalaman langsung (direct/vicarious experience), persuasi verbal, kondisi psikologis dan fisiologis seseorang. Self-efficacy akademik diartikan sebagai keyakinan mahasiswa terhadap kemampuannya untuk melaksanakan dan mengorganisasikan suatu kegiatan tertentu dengan baik. Makin seseorang merasa yakin terhadap kemampuan yang dimilikinya, maka makin besar usaha yang dilakukannya dan makin aktif ia karena ia yakin kemampuannya itu dapat membantu dalam mengerjakan suatu tugas menghadapi hambatan/rintangan untuk mencapai prestasi akademik yang tinggi.

Hasil penelitian Lampert (2007) mengenai hubungan antara self- efficacy akademik, konsep diri akademik dan prestasi akademik menunjukkan bahwa self-efficacy akademik adalah prediktor yang lebih signifikan yang digunakan dalam memprediksi prestasi akademik dibandingkan dengan konsep diri akademik. Menurut Azwar (2004), ada dua faktor yang memengaruhi prestasi akademik seseorang, yaitu faktor internal dan faktor eksternal. Faktor internal meliputi faktor fisik dan faktor psikologi. Faktor fisik berhubungan dengan kondisi fisik secara umum, seperti pendengaran, penglihatan, struktur tubuh. Sedangkan untuk faktor psikologi menyangkut faktor non fisik, meliputi kecerdasan, bakat dan kecakapan (prestasi yang telah dimiliki), dan unsur kepribadian seperti sikap, minat, motivasi, inteligensi, bakat dan kesehatan mental. Faktor eksternal meliputi faktor fisik dan faktor sosial. Faktor fisik menyangkut tempat belajar, sarana dan perlengkapan belajar, materi dan kondisi lingkungan belajar. Faktor sosial menyangkut dukungan sosial, adat istiadat, pengetahuan, teknologi, dan pengaruh budaya.

Faktor lain yang memengaruhi prestasi akademik adalah faktor karakteristik kepribadian individu mahasiswa. Beberapa literatur tentang hubungan antara prestasi dan konsep diri pada remaja memberikan bukti bahwa konsep diri akademik dapat menjadi alat prediksi kinerja akademik (prestasi 
mahasiswa). Menurut Trautwein dan Ludtke (dalam Rumijati, 2010) efek timbal-balik telah ditemukan antara domain spesifik konsep diri akademik (yang dapat diukur dengan DOSC=Dimensions Of Self Concept) dan prestasi akademik. Salah satu simpulan penting dalam penelitian mengenai domain spesifik konsep diri akademik tersebut adalah bahwa konsep diri akademik merupakan prediktor yang signifikan terhadap prestasi akademik.

Selain self-efficacy akademik prestasi akademik juga dipengaruhi oleh konsep diri akademik. Menurut Atmasari (2009), konsep diri akademik adalah penilaian seseorang terhadap kemampuan akademiknya. Konsep diri akademik meliputi kemampuan dalam mengikuti perkuliahan, kemampuan dalam meraih prestasi di dalam bidang akademik, serta aktivitas di kampus atau di dalam kelas yang juga berkaitan dengan persepsi, pikiran, perasaan, dan penilaian seseorang terhadap kemampuan akademikya.

Konsep diri akademik adalah penilaian seseorang terhadap kemampuan akademiknya, yang meliputi kemampuan dalam mengikuti kuliah/pelajaran, kemampuan dalam meraih prestasi di bidang akademik, serta aktivitas di kampus atau di dalam kelas yang juga berkaitan dengan persepsi, pikiran, perasaan, dan penilaian seseorang terhadap kemampuan akademikya (Atmasari, 2009). Bong dan Skaalvik (2003) menyatakan bahwa konsep diri akademik terutama menunjukkan satu keyakinan diri, kemampuan dalam bidang akademik tertentu, sedangkan self-efficacy akademik terutama menunjukkan diri sendiri-keyakinan dianggap berhasil melakukan tugas akademis tertentu. Self efficacy akademik biasanya diukur pada tingkat spesifik tugas, sementara konsep diri akademik biasanya diukur pada tingkat yang lebih umum.

Bandura (1997), self-efficacy dapat diperoleh, dipelajari dan dikembangkan dari empat sumber informasi, yang merupakan faktor-faktor yang memengaruhi self-efficacy. Keempat faktor tersebut adalah pengalaman keberhasilan dan pencapaian prestasi, pengalaman orang lain, persuasi verbal, keadaan fisiologis dan psikologis. Hasil penelitian Darminto (2004) menunjukkan hubunganhubungan antarvariabel terkait konsep diri akademik dengan gejala mahasiswa kurang berprestasi, hubungan antara tingkat dukungan belajar dari orangtua dengan status sosial ekonomi orangtua dengan konsep diri akademik.

Bong dan Skaalvik (2003) menyatakan bahwa konsep diri akademik terutama menunjukkan satu keyakinan diri, kemampuan dalam bidang-bidang akademik tertentu, sedangkan self-efficacy akademik terutama menunjukkan diri sendiri-keyakinan dianggap berhasil melakukan tugas akademik tertentu. Self efficacy akademik biasanya diukur pada tingkatan yang khusus pada tugas tertentu, sementara konsep diri akademik biasanya diukur pada tingkat yang lebih umum. Contoh perbedaan antara self-efficacy dan konsep diri akademik, dijelaskan oleh Pajares (2001) - jika belajar dalam domain yang sama (contoh matematika), self-efficacy akademik menunjukkan seberapa yakin seseorang menyelesaikan persamaan kuadrat dalam matematika (mengukur kompetensi dirinya pada tugas tingkat tertentu). Sementara itu, untuk konsep diri akademik pada kasus yang sama seseorang tersebut baik/mahir di matematika membandingkan diri dengan orang lain yang seusia, atau dengan kata lain seseorang tersebut salah satu siswa terbaik di kelas. Berdasarkan uraian tersebut, penelitian bermaksud melihat hubungan self-efficacy akademik dan konsep diri akademik terhadap prestasi akademik mahasiswa.

\section{METODE PENELITIAN}

Subjek dalam penelitian ini adalah mahasiswa semester 4 ke atas, yang terdaftar aktif secara terus-menerus di Fakultas/Jurusan Psikologi Universitas Swasta di Jakarta yang melibatkan 192 mahasiswa. Alasan pemilihan partisipan penelitian ini adalah mahasiswa aktif belum pernah 
mengambil cuti kuliah dan untuk mahasiswa semester 4 ke atas sudah mempunyai nilai Indeks Prestasi Kumulatif (IPK). Data penelitian diperoleh dari data prestasi akademik mahasiswa berupa Indeks Prestasi Kumulatif (IPK) di bagian kemahasiswaan Fakultas/Jurusan Psikologi Universitas Swasta di Jakarta (Tabel 1).

Tabel 1 Data IPK Mahasiswa Fakultas Psikologi Universitas Swasta di Jakarta

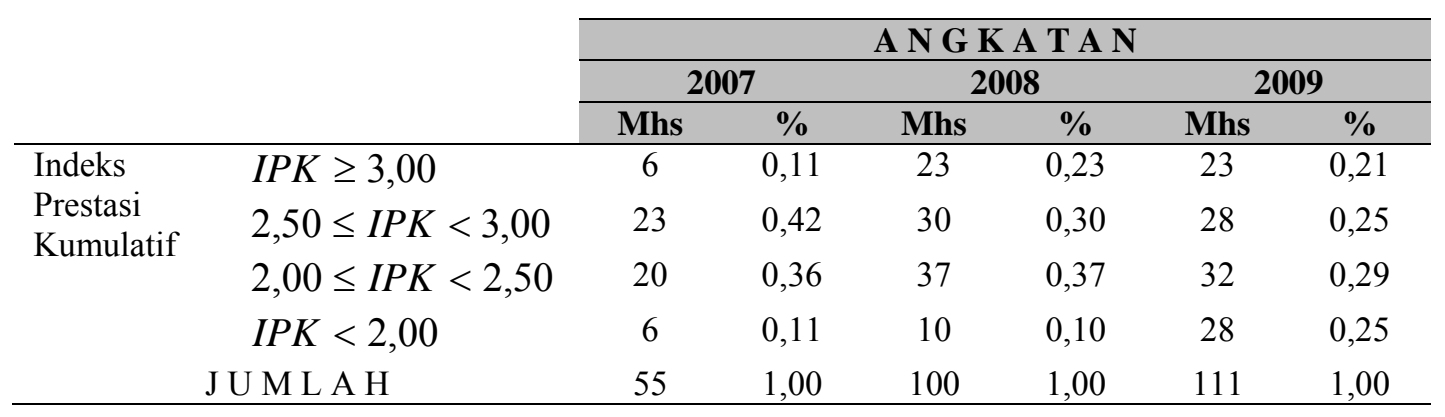

(Sumber: IT Support Universitas Swasta di Jakarta)

Pengambilan sampel dilakukan adalah dengan menggunakan Teknik convenience sampling. Variabel penelitian meliputi variabel Konsep Diri Akademik, Self-efficacy Akademik, Variabel Prestasi akademik. Penelitian ini dilakukan dengan menggunakan rancangan deskriptif dan korelasional. Sedangkan instrumen yang digunakan dalam penelitian ini diambil dari nilai skor setiap instrumen yang dibuat dalam bentuk kuesioner yang disebarkan untuk diisi ke setiap responden. Kuesioner ini dibuat berdasarkan teori dan aspek yang mengacu pada uraian-uraian yang telah dipaparkan. Selanjutnya dibuat pernyataan-pernyataan untuk dipilih sesuai dengan pendapat responden. Instrumen alat ukur meliputi variabel bebas (independent), Self-efficacy Akademik $\left(x_{1}\right)$, Konsep Diri Akademik $\left(x_{2}\right)$, dan sebagai variabel terikat (dependent) Prestasi Akademik $(y)$.

Pengukuran variabel penelitian terdiri atas dua bagian. Bagian pertama adalah untuk karakteristik mahasiswa meliputi jenis kelamin partisipan (laki-laki, perempuan), kategori semester $(4,6,8)$, Indeks Prestasi kumulatif (IPK), tempat tinggal (dengan orangtua, kos, dengan famili), asal daerah partisipan (Jabodetabek, Jawa non-Jabodetabek, lainnya). Sedangkan bagian kedua adalah pertanyaan sesuai dengan variabel yang diukur (self-efficacy akademik, konsep diri akademik). Semua pertanyaan dalam kuesioner diukur dengan menggunakan skala likert. Untuk variabel konsep diri akademik, skala likert lima poin dengan titik "Sangat Tidak Setuju" hingga "Sangat Setuju" (Sangat Tidak Setuju, Tidak Setuju, Netral, Setuju, Sangat Setuju), yang meliputi 30 pertanyaan. Untuk variabel prokrastinasi akademik, skala likert lima point dengan titik "Tidak Pernah" hingga "Selalu" (Tidak Pernah, Hampir Tidak Pernah, Kadang-kadang, Hampir Selalu, Selalu), yang meliputi 44 pertanyaan. Sedangkan variabel Self-efficacy akademik, dengan titik "Sangat Tidak Percaya Diri" hingga "Sangat Percaya Diri", yang meliputi 33 pertanyaan.

Semua data dan informasi yang telah diperoleh merupakan data kasar. Data tersebut dianalisis secara statistik, dengan bantuan program komputer SPSS 17.0 for Windows, hasil uji coba alat ukur berkategori memenuhi syarat nilai Alpha Cronbach's (minimal 0,70). Untuk skala konsep diri akademik, nilai alpha cronbach's bernilai 0,701, skala self-efficacy akademik dengan nilai alpha cronbach's bernilai 0,944 (Tabel 2). 
Tabel 2 Nilai Cronbach's Alpha Uji Coba Alat Ukur

\begin{tabular}{lc}
\hline \multicolumn{1}{c}{ Alat Ukur } & Cronbachh's Alpha \\
\hline Konsep Diri Akademik (KDA) & 0,701 \\
Self-Efficacy Akademik (SE) & 0,944 \\
\hline
\end{tabular}

(Sumber : Data hasil olahan SPSS versi 17.0)

Untuk analisis regresi, penelitian menggunakan teori regresi dan korelasi dengan menggunakan kerangka pikir berdasarkan pada penjelasan teoritis sebagaimana yang telah dikemukakan dari pendahuluan. Kerangka berpikir ini digambarkan secara skematis seperti bagan berikut.

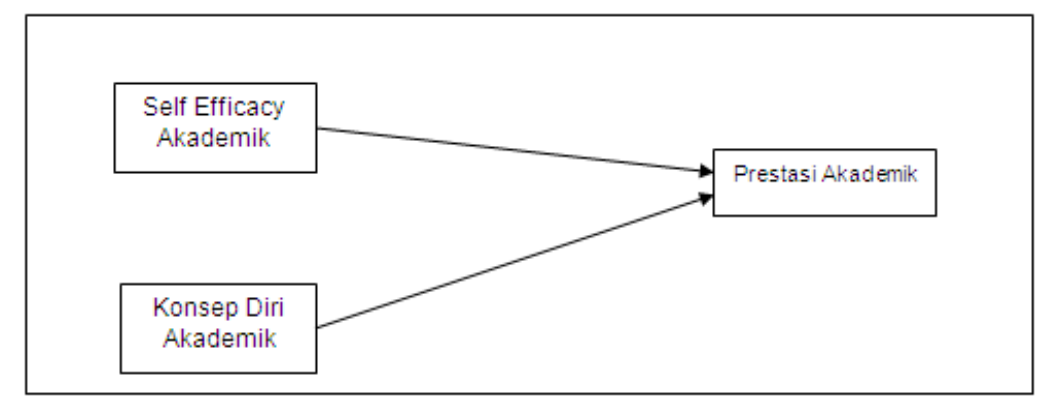

Gambar 1 Hubungan Antara Self-Efficacy Akademik dan Konsep Diri akademik dengan Prestasi Akademik

Dari bagan tersebut tersebut dapat dibaca bahwa 2 variabel yakni self-efficacy akademik dan konsep diri akademik memengaruhi prestasi akademik, dengan hubungan antara self-efficacy akademik dan konsep diri akademik sebagai variabel bebas (independent variable) dengan prestasi akademik sebagai variabel terikat (dependent variable).

\section{HASIL DAN PEMBAHASAN}

Pembahasan dalam penelitian ini meliputi analisis statistik deskriptif (profil responden) dan analisis regresi dan korelasi antara variabel bebas(Self-Efficacy Akademik dan Konsep Diri Akademik) dan variabel terikat (Konsep Diri Akademik). Responden berasal dari mahasiswa Fakultas Psikologi di Universitas Swasta di Jakarta Barat, tempat penelitian berlangsung. Pengolahan data terhadap kuesioner yang dibagikan kepada 192 partisipan dapat diketahui karakteristik yang digolongkan menurut jenis kelamin partisipan (laki-laki, perempuan), kategori semester $(4,6,8)$, tempat tinggal (dengan orang tua, kost, dengan famili), asal daerah partisipan (Jabodetabek, Jawa nonJabodetabek, lainnya).

Profil responden berdasarkan jenis kelamin, menunjukkan mayoritas responden berjenis kelamin perempuan, 150 responden $(78,1 \%)$, sisanya 42 responden $(21,9 \%)$ berjenis kelamin laki-laki.

Tabel 3 Profil Responden Berdasarkan Jenis Kelamin

\begin{tabular}{lrrrr} 
& Frekuensi & Persen & Persen Valid & $\begin{array}{c}\text { Persen } \\
\text { Kumulatif }\end{array}$ \\
\hline Laki-laki & 42 & 21,9 & 21,9 & 21,9 \\
Perempuan & 150 & 78,1 & 78,1 & 100,0 \\
Total & 192 & 100,0 & 100,0 & \\
\hline
\end{tabular}


Profil responden berdasarkan kategori semester meliputi antara lain 92 responden $(47,9 \%)$ dari semester 4, 69 responden $(35,9 \%)$. Sedang sisanya dari semester 8, sebesar 31 responden $(16,2 \%)$.

Tabel 4 Profil Responden Berdasarkan Kategori Semester

\begin{tabular}{crrrr}
\hline & Frekuensi & Persen & \multicolumn{1}{c}{$\begin{array}{c}\text { Persen } \\
\text { Valid }\end{array}$} & $\begin{array}{c}\text { Persen } \\
\text { kumulatif }\end{array}$ \\
\hline 4 & 92 & 47,9 & 47,9 & 47,9 \\
6 & 69 & 35,9 & 35,9 & 83,9 \\
8 & 31 & 16,1 & 16,1 & 100,0 \\
Total & 192 & 100,0 & 100,0 & \\
\hline
\end{tabular}

Profil responden berdasarkan tempat tinggal meliputi 132 responden $(68,8 \%)$ tinggal bersama orangtua, 52 responden $(27,1 \%)$ tinggal di kos. Sisanya 8 responden $(4,2 \%)$ tinggal dengan famili.

Tabel 5 Profil Responden Berdasarkan Tempat Tinggal

\begin{tabular}{lrrrr} 
& Frekuensi & Persen & $\begin{array}{c}\text { Persen } \\
\text { Valid }\end{array}$ & $\begin{array}{c}\text { Persen } \\
\text { kumulatif }\end{array}$ \\
\hline Dengan Orangtua & 132 & 68,8 & 68,8 & 68,8 \\
Kos & 52 & 27,0 & 27,0 & 95,8 \\
Dengan Famili & 8 & 4,2 & 4,2 & 100,0 \\
Total & 192 & 100,0 & 100,0 & \\
\hline
\end{tabular}

Profil responden berdasarkan asalnya menghasilkan 149 responden $(77,69 \%)$ dari Jabodetabek, 15 responden $(7,89 \%)$ dari Jawa non-Jabodetabek. Sisanya 28 responden $(14,6 \%)$ lainnya,

Tabel 6 Profil Responden Berdasarkan Asal

\begin{tabular}{lrrrr}
\hline & Frekuensi & Persen & $\begin{array}{c}\text { Persen } \\
\text { Valid }\end{array}$ & $\begin{array}{c}\text { Persen } \\
\text { kumulatif }\end{array}$ \\
\hline Jabodetabek & 149 & 77,6 & 77,6 & 77,6 \\
Jawa Non Jabodetabek & 15 & 7,8 & 7,8 & 85,4 \\
Lainnya & 28 & 14,6 & 14,6 & 100,0 \\
Total & 192 & 100,0 & 100,0 & \\
\hline
\end{tabular}

\section{Hubungan antara Self-Efficacy dan Konsep Diri Akademik dengan Prestasi Akademik}

Analisis regresi menunjukkan Angka R sebesar 0,367 (Tabel 7) menunjukkan bahwa korelasi antara variabel terikat (prestasi akademik) dengan 2 variabel bebas (self-efficacy akademik dan konsep diri akademik) adalah cukup.

Tabel 7 Model Summary Self-Efficacy Akademik dan Konsep diri akademik dengan Prestasi Akademik

\begin{tabular}{rrrrr} 
Model & R & R Square & Adjusted R Square & $\begin{array}{c}\text { Std. Error of the } \\
\text { Estimate }\end{array}$ \\
\hline & $.367(\mathrm{a})$ & .135 & .125 & .45693 \\
\hline
\end{tabular}

a Predictors: (Constant), Skor Self efficacy Akademik dan Konsep diri Akademik 
Angka $\mathrm{R}^{2}$ sebesar 0,135 (Tabel 8) menunjukkan bahwa 13,5\% variasi dari prestasi akademik dijelaskan oleh dua variabel bebas tersebut. Sisanya $86,5 \%$ dijelaskan oleh sebab-sebab lain (faktorfaktor tak terkontrol artinya faktor di luar self-efficacy akademik dan konsep diri akademik)

Tabel 8 ANOVA (b) Self-Efficacy Akademik dan Konsep diri Akademik dengan Prestasi Akademik

\begin{tabular}{llrrrrr}
\hline Model & & Sum of Squares & df & Mean Square & \multicolumn{1}{c}{ F } & Sig. \\
\hline 1 & Regression & 6.132 & 2 & 3.066 & 14.686 & $.000(\mathrm{a})$ \\
& Residual & 39.460 & 189 & .209 & & \\
& Total & 45.593 & 191 & & & \\
\hline
\end{tabular}

a Predictors: (Constant), Skor Self efficacy Akademik dan Skor Konsep diri Akademik

b Dependent Variable: Skor Prestasi Akademik

Uji ANOVA atau $\mathrm{F}$ test (Tabel 8), didapat $\mathrm{F}$ hitung 94,187 dengan tingkat signifikansi 0,000. Karena probabilitas $(0,000)<(0,05)$, model regresi bisa dipakai untuk memprediksi pretasi akademik, atau bisa dikatakan bahwa self-efficacy akademik dan konsep diri akademik secara bersama-sama berpengaruh terhadap pretasi akademik.

Tabel 9 Coefficients(a) Kegiatan Anak, Relasi Anak dan Transaksi Dukungan Sosial

\begin{tabular}{|c|c|c|c|c|c|c|}
\hline \multirow{2}{*}{\multicolumn{2}{|c|}{ Model }} & \multicolumn{2}{|c|}{$\begin{array}{l}\text { Unstandardized } \\
\text { Coefficients }\end{array}$} & \multirow{2}{*}{$\begin{array}{c}\begin{array}{c}\text { Standardized } \\
\text { Coefficients }\end{array} \\
\text { Beta } \\
\end{array}$} & \multirow{2}{*}{$\begin{array}{l}\mathbf{T} \\
\mathbf{B}\end{array}$} & \multirow{2}{*}{$\begin{array}{c}\text { Sig. } \\
\text { Std. Error }\end{array}$} \\
\hline & & B & Std. Error & & & \\
\hline \multirow[t]{3}{*}{1} & (Constant) & 2.339 & .487 & & 4.926 & .000 \\
\hline & $\begin{array}{l}\text { Skor Self-Efficacy } \\
\text { Akademik }\end{array}$ & .010 & .002 & .351 & 5.176 & .001 \\
\hline & $\begin{array}{l}\text { Skor Konsep Diri } \\
\text { Akademik }\end{array}$ & -.008 & .005 & -.122 & -1.808 & .000 \\
\hline
\end{tabular}

a Dependent Variable: Skor Prestasi Akademik

Hubungan linier antara Self-Efficacy Akademik dan Konsep diri akademik dengan Prestasi Akademik berbentuk persamaan regresi $y=2,339+0,01 x_{1}-0,008 x_{2}$, dengan $y$ adalah Prestasi Akademik (variabel terikat) dan $x_{1} \& x_{2}$ adalah Skor Self-Efficacy Akademik dan Skor Konsep Diri Akademik ( variabel bebas). Uji hipotesa konstanta $\left(b_{0}\right)$ nilai Sig $(0,000)<(0.05)$, artinya faktorfaktor tak terkontrol $b_{o}$ berpengaruh terhadap Prestasi Akademik. Uji koefisien regresi Self-Efficacy Akademik $\left(b_{1}\right)$ terlihat nilai Sig $(0,001)<(0.05)$, artinya Self-Efficacy Akademik berkorelasi secara nyata terhadap Prestasi Akademik atau bisa dikatakan Self-Efficacy Akademik memengaruhi Prestasi Akademik.

Untuk koefisien regresi variabel Self-Efficacy Akademik memperlihatkan arah korelasi positif, artinya makin tinggi skor variabel bebas (Self-Efficacy) makin tinggi pula variabel terikatnya (Prestasi Akademik). Sedangkan koefisien regresi variabel Konsep Diri Akademik memperlihatkan sebaliknya (arah korelasi negatif). Skor Self-Efficacy Akademik $(0,01)$ artinya bahwa setiap setiap penambahan $($ karena tanda + ) 1 satuan, maka setiap skor Self-Efficacy Akademik akan meningkatkan Prestasi Akademik sebesar 0,01. Koefisien regresi Skor Konsep Diri Akademik $(-0,008)$ artinya bahwa setiap penambahan (karena tanda - ) 1 satuan skor Konsep Diri Akademik akan mengurangi Prestasi Akademik sebesar 0,08. 
Tabel 10 menunjukkan bahwa semua variabel (Self-Efficacy Akademik, Konsep Diri Akademik, Prestasi Akademik) saling berkorelasi satu dengan lainnya (berkorelasi positif dan negatif) walaupun lemah, berkorelasi positif dan negatif, terlihat adanya tanda bintang $(* *)$.

Tabel 10 Correlations Self-Efficacy Akademik, Konsep Diri Akademik, Prestasi Akademik

\begin{tabular}{llrrr}
\hline & & $\begin{array}{c}\text { Skor Self-Efficacy } \\
\text { Akademik }\end{array}$ & $\begin{array}{c}\text { Skor Konsep Diri } \\
\text { Akademis }\end{array}$ & $\begin{array}{c}\text { Skor Prestasi } \\
\text { Akademik }\end{array}$ \\
\hline $\begin{array}{l}\text { Skor Self-Efficacy } \\
\text { Akademik }\end{array}$ & Pearson Correlation & 1 & $.039(* *)$ & $\left..346^{* *}\right)$ \\
& Sig. (2-tailed) & & .000 & .000 \\
& $\mathrm{~N}$ & 192 & 192 & 192 \\
$\begin{array}{l}\text { Skor Konsep Diri } \\
\text { Akademik }\end{array}$ & Pearson Correlation & $.039(* *)$ & 1 & $.109(* *)$ \\
& Sig. (2-tailed) & .000 & 192 & .000 \\
Skor Prestasi & $\mathrm{N}$ & 192 & $.109(* *)$ & 192 \\
Akademik & Pearson Correlation & $.346(* *)$ & .000 & 1 \\
& Sig. (2-tailed) & .000 & 192 & 192 \\
\hline
\end{tabular}

** Correlation is significant at the 0.01 level (2-tailed).

Penelitian menunjukkan bahwa variabel Self-Efficacy Akademik dan variabel Konsep Diri Akademik yang berperan memengaruhi prestasi akademik sejalan dengan hasil penelitian Warsito (2004). Prestasi akademik dicapai mahasiswa lebih banyak disebabkan hubungan kausal secara langsung oleh self-efficacy daripada secara tidak langsung melalui konsep diri akademik.

\section{SIMPULAN}

Analisis regresi hubungan antara 2 variabel bebas (Self-Efficacy Akademik, Konsep Diri Akademik) dengan varibel terikat (Prestasi Akademik) $y=2,399+0,010 x_{1}-0,008 x_{2}$. Hubungan variabel Self-efficacy Akademik dan Konsep Diri Akademik dengan variabel Prestasi Akademik, bahwa Self-efficacy Akademik berpengaruh secara signifikan terhadap Prestasi Akademik di Fakultas Psikologi penelitian dilakukan.

Berdasarkan hasil analisis, peneliti mengemukakan beberapa saran, antara lain sebagai berikut. Meskipun nilai cronbach's alpha dalam uji pengukuran untuk mengukur tingkat keandalan dari kuesioner hasilnya cukup baik untuk semua variabel penelitian (Konsep Diri Akademik, maupun Selfefficacy Akademik), ketika dilakukan nilai koefisien regresi untuk variabel Konsep Diri Akademik adalah negatif. Dengan demikian perlu dilakukan penelitian lebih lanjut mengenai faktor-faktor yang memengaruhi Konsep Diri Akademik terhadap prestasi akademik, misalnya jika ada pola karakteristik perilaku, kepribadian maupun kecerdasan yang berperan dalam pencapaian prestasi akademik.

Dalam penelitian ini, pengukuran hanya dilakukan dalam bentuk kuantitatif, selanjutnya disarankan untuk juga menggunakan data kualitatif yang diperkirakan akan lebih baik dari hasil wawancara dengan partisipan serta observasi pada partisipan, agar mendapatkan hasil uji yang lebih objektif. Di samping itu, penelitian ini hanya dalam lingkup fakultas, sehingga hasil yang didapatkan dari uji hipotesis tidak sesuai dengan model yang diharapkan, untuk itu disarankan pada para peneliti selanjutnya untuk ruang lingkup yang lebih luas, misalnya dalam lingkup universitas. 


\section{DAFTAR PUSTAKA}

Atmasari. (2009). Studi Deskriptif Mengenai Konsep Diri Akademik dan Perencanaan Karier Pada Remaja Yang Memiliki Orang Tua Sebagai Tenaga Kerja Indonesia, Skripsi, Fakultas Psikologi Diunduh dari: http//alumni.unair.ac.id/kumpulanfile/743829930. abs.pdf., 30 Nopember 2011.

Azwar, S. (2004). Sikap manusia teori dan pengukurannya (Ed. 4). Yogyakarta: Pustaka Pelajar.

Bandura. (1997). Social learning theory. New Jersey: Prentice Hall.

Darminto. (2004). Hubungan Antara Konsep Diri Akademik dan Latar Belakang Keluarga Dengan Capaian Prestasi Kurang, Journal Psikologi. Vol. 14. No. 2, hal.16-37.

Kamus Bahasa Indonesia Online. (n.d.). Diakses 4 November 2011 dari http://kamusbahasaindonesia.org/pendidikan.

Lampert, J. (2007). The Relationship of Self-Efficacy and Self-Concept To Academic Performance In A College Sample : Testing Competing Models and Measures. School of Professional Psychology Pacific University.

Pajares, (2001). The Development of academic self-efficacy. San Diego: Academic Press.

Rumijati., A. (2010). Dimensi Pengembangan Diri bagi Mahasiswa. Diunduh dari http://rumijati.staff.umm.ac.id/2010/04/10/dimensi-pengembangan-diri-bagi-mahasiswa/ , 3 Desember 2011.

Setiawan. (2000). Meraih nilai akademik maksimal. Diunduh dari http://www. pendtinggi.com/nilai098+akademik/html, 3 Desember 2011.

Warsito. (2004). Hubungan antara self-efficacy dengan penyesuaian akademik dan prestasi akademik. Jurnal Psikologi, 14(2), hal. 92 - 109 